\title{
The Role of Service Encounter Interaction Behavior in Activating Customer Participation and Co-Creating Value in the Health Care Service
}

\author{
LE NGUYEN HAU
}

School of Industrial Management, HCMC University of Technology - lnhau@ hcmut.edu.vn PHAM NGOC TRAM ANH

School of Industrial Management, HCMC University of Technology - pntanh@ @cmut.edu.vn PHAM NGOC THUY

School of Industrial Management, HCMC University of Technology - pnthuy@ hcmut.edu.vn TRAN THI PHUONG THAO

School of Industrial Management, HCMC University of Technology - ttpthao@ hcmut.edu.vn DAO THI XUAN MAI

Maastricht MBA Programme, HCMC University of Technology - mai.x.dao@gsk.com

This research was funded by Vietnam National University, Ho Chi Minh City under grant number B2014-20-02.

\section{ARTICLE INFO ABSTRACT}

\section{Article history:}

Received:

Aug. 62015

Received in revised form:

Jan. 82016

Accepted:

Mar. 252016
This research aims to explore the role of service encounter behaviors and customers' participation in the interaction process to co-create value, leading to customer satisfaction. A model is developed and tested in the health care context. Based on the data of 320 paired patient-physician cases, the analysis reveals that physician's interactions are critical customer-oriented behaviors, which directly affect customer value. More importantly, it plays a key role in activating the customer participation in a service creation. From the customer view, although actively engaging in a service requires more resources, it is worthy because it creates much more value-in-use.

Keywords:

value co-creation, customer participation, provider interaction behavior, health care service, Vietnam. 


\section{Introduction}

In recent years the participation of customers in a service has received increasing attention from marketing academia as well as practitioners. Several studies have attempted to provide insights into the nature of customer participation, its mechanism, antecedents, and consequences (Alam, 2011; Bitner et al., 1997; Lovelock \& Young, 1979; Ordanini \& Parasuraman, 2010; Ramaswamy \& Gouillart, 2010; Tanev et al., 2011). Terms such as co-producer (Wikström, 1996), "partial" employee (Larsson \& Bowen, 1989), and value co-creator (Vargo \& Lusch, 2004) have been suggested in the marketing literature to highlight customer's participative role in a service.

The service dominant logic (Vargo \& Lusch, 2004) and service logic (Grönroos, 2008) advocated that in the process of need-fulfillment, customers are the co-creator of value for themselves, and the service provider is not a supplier of value but a facilitator of the customer's value creation process. Service scholars indicated further that customers and service firm co-create value through resource integration and interaction (Gummesson \& Mele, 2010; Vargo et al., 2008). Despite this important notion, few studies have clearly analyzed the specific roles of service provider and the customer in the value co-creation process (Grönroos \& Voima, 2013). It seems that research that provides insights into the interaction behaviors of customers and a service firm (i.e. the service encounters) to create customer value is scant (e.g., Smith, 2013; Zolnierek \& DiMatteo, 2009). Moreover, as individual customer has different levels of resources and willingness to participate actively in the service process, it is essential to understand how a service encounter can help mobilize customers to participate in the service process (Bitner et al., 2014).

In this context the primary purpose of this research is to explore the role of interaction behavior of service encounters in the value co-creation process. Particularly, it is to address two major questions. Firstly, to what extent does a service frontliner's interaction behavior activate customer participation? Secondly, does a service frontliner's interaction behavior directly contribute to perceived value? In addition to enforcing our knowledge of the role of service encounters in the interaction with customers, this study seeks to underpin the literature by providing more insights into the mechanism of service encounter-customer interaction to co-create value.

This research problem is specifically imperative in the health care context, where customers (or patients) are no longer considered as passive recipients of medical 
treatment, but actually play a more active role in improving the effectiveness of therapeutic activities (McColl-Kennedy et al., 2012). In this regard, Bodenheimer et al. (2002) suggested considering patient-professional partnership as the new paradigm of chronic disease management. In this partnership, physicians (doctors) are experts in treating diseases, and patients are experts in their own lives and conditions. Thus, the collaboration process between a patient (customer) and a physician (service encounter) would be critical for the successful outcomes for customers (Yi \& Gong, 2013).

The rest of this paper is organized as follows. The next section will present the theoretical background of key concepts, followed by the development of proposed hypotheses. Research design will then be reported and featured by a dyadic approach to data collection. Data analysis, result discussion, and implications are included in the final sections of the paper.

\section{Theoretical background}

\subsection{Customer participation behaviors to co-create value}

In a broad sense, value co-creation is described as a process in which efforts are combined among firms, employees, customers, stockholders, government agencies, and other entities related to any given exchange, but is always determined by the beneficiary (e.g., customer) (Vargo et al., 2008). In this process customers and the service firm hold crucial roles, and interaction between them is the key to value co-creation (Grönroos \& Voima, 2012). In the interaction the firm engages in the customer's value creation process as a value facilitator, and the customer himself becomes a collaborator with the service provider as a co-producer (Grönroos, 2008).

From the behavioral view Yi and Gong (2013) described customer co-creation behaviors as a construct made up of two components: participation behaviors and citizenship behaviors. Participation behaviors are an integral component of the production of a service. On the other hand, citizenship behaviors are customer activities related to the service, but out of the service process. These citizenship behaviors are not compulsory for the service creation and thus are beyond the scope of this current study.

Customer participation behaviors occur during the direct interaction with service encounter and are necessary to attain a proper performance in the service co-creation process (Kelley et al., 1990). This concept has evolved from the interference of customer in service production (Levitt, 1972) into the engagement of customer in value creation 
(Grönroos \& Ravald, 2011; Lusch \& Vargo, 2006). Several studies have stressed that customer participation behaviors can only occur in an interaction in the joint sphere of the service (Chan et al., 2010; Grönroos, 2008; Yi et al., 2011). Specifically, Yi and Gong (2013) identified four dimensions of customer participation behaviors which represent the value co-creation process: (i) information seeking-customers actively look for information about how to perform their tasks, what they are expected to do, and how they are expected to perform those tasks, in order to understand the nature of service and their roles in the value co-creation process; (ii) information sharing-customers share relevant information and expectation to help firms understand their particular needs and expectations; (iii) responsible behavior - customers recognize their duty and take responsibility to coordinate and ensure successful cooperation; and (iv) personal interaction-interpersonal relations between customers and employees, which are manifested by social aspects such as courtesy, friendliness, and respect.

\subsection{Service providers' interaction behaviors}

In an effort to bring the service dominant logic perspective into practice, Karpen, et al. (2014) introduced a framework of a firm's interaction capabilities to co-create value with customers. These interaction capabilities are then reflected by six corresponding manifestations as behaviors to facilitate the value co-creation process with customers. They include: (i) individuated interaction — behavior aiming to understand individual customers' unique contexts, their preferences, and expected outcomes; (ii) relational interaction - behavior to improve social and emotional connections with customers in the service process; (iii) ethical interaction - behavior to reflect a fair manner towards customers in the service context; (iv) empowered interaction - behavior to empower customers to utilize their skills to shape the nature and content of exchange in the service process; (v) developmental interaction - behavior to assist customers in upgrading their knowledge, competence, and skills; and (vi) concerted interaction-behavior to facilitate, coordinate, and integrate customers in the service process. These six types of behaviors also reflect the resource integration mechanism of the service firm in the value co-creation process. Karpen et al. (2014) suggested that implementing these is an effective strategy to drive customer-related participative performances, leading to perceived value, satisfaction, trust, repurchase intention, and positive word-of-mouth. 


\subsection{Customer perceived value}

Perceived value, which is often understood as the overall assessment of the trade-off associated with customers' experiences based on the perceptions of what is received and what is given (Zeithaml, 1988), can be considered one of the main reasons for customers' engagement with an organization. It is particularly vital for firms to understand how to deal with and manage customer interactions in the value co-creation process. Otherwise, customers may perceive less value, and this leads to unexpected outcome (Sinnya, 2014).

Sweeney and Soutar (2001) proposed four dimensions to explain customers' perceived value, including emotional, social, functional value (quality/performance), and price dimensions. In the context of health care service, the functional value and emotional value are the most important to patients' perception of service value since health care is regarded as 'high credence' services due to the need for high levels of trust in health care professionals and its impacts on the quality of life (Venkatesh \& Balaji, 2012). Therefore, the functional and emotional value (the utility generated from the performance of an expected service and from feeling or affective mood through the service) will play the key roles in measuring perceived value in this study.

\section{Proposed hypotheses}

\subsection{Provider interaction behavior, customer participation, and perceived value}

Interaction behaviors of the service provider are important to activate customer participation and ensure the success of value co-creation. When using a service, each customer has a certain degree of resources such as knowledge and skills that may contribute to the service process (Grönroos, 2008). However, to activate these customer resources, the service firm needs to have certain behaviors to encourage customers to contribute their knowledge and skills and interact as a co-creator of value (Prahalad \& Ramaswamy, 2000). As value is created in usage, interaction can make the value creation process of customers accessible by service providers and can provide them with an opportunity to influence customer's experiences in the joint sphere and take part in the customer's value creation process as a co-creator (Grönroos \& Voima, 2013). Therefore, the service provider behaviors to interact with customer and enhance collaboration are expected to have positive effects on the extent of customer participation. 
In the health care service, behaviors to foster two-way communication or to open dialogues between physicians and patients are also necessary to provide patients with the needed social or emotional support, thus making them feel at ease and psychologically comfortable during treatment and keeping them engaging in value cocreation (Eldh et al., 2006). As patients often possess little knowledge of their illness and therefore feel stressed and emotional (Berry \& Bendapudi, 2007), the more pleasant and positive the social environment, the more likely patients would be to collaborate in the treatment process (Lengnick-Hall et al., 2000). Moreover, as physicians attempt to share all relevant and non-misleading information during discussion or are willing to clarify any potential risks associated with certain types of treatment, patients' confidence can also be built, potentially leading to their active participation (Eldh et al., 2006).

Physician's interaction behavior with patients in an individual basis is also critical to foster participation. Different patients, even with the same medical condition, may have completely different circumstances or context. If physicians are capable of approaching patients individually and having a more thorough understanding of their idiosyncratic conditions (such as medical condition, their unique circumstance, preference for particular treatment options, and expected outcome of treatment), they can offer solutions that better fit each individual patient's expectation, which in turn will enhance the collaboration and the value being created (Bitner et al. 1997).

Furthermore, patients would be more willing to comply with the treatment options that they have jointly developed with physicians (Prahalad \& Ramaswamy, 2004). If physicians are open to their suggestions and constantly provide feedback for preferred treatment option, patients will be more willing to get involved in the treatment process, and value co-creation will be facilitated and enhanced.

In combination, as physicians can interact with patients in an individual, relational, and concerted manner, patients would be more willing to take an active participation role in value co-creation, and the value perceived by patients would also be increased. It is, therefore, hypothesized that:

H1: Physician interaction behaviors have a positive impact on patient participation.

H2: Physician interaction behaviors have a positive impact on patients' perceived value. 


\subsection{Customer participation and perceived customer value}

Kellogg et al. (1997) suggested that treating customer participation as a variable of their own value equation can create more implications for both researchers and managers. Within the health care context, patient participation in the treatment process can be demonstrated through various types of behaviors.

First, patients may seek information to clarify service requirements and to understand the nature of service and their roles in the value co-creation process, thus helping them become more integrated into this process (Kelley et al., 1990; Kellogg et al., 1997; Yi \& Gong, 2013). With adequate information patients would feel more confident; uncertainty would be reduced, and they would be ready to cooperate with physicians and become more active in the value co-creation process.

Second, they may also express opinions, state preferences, and explore options (Cegala et al., 2007). By providing physicians with proper information and honestly answering all treatment-related questions, patients could motivate physicians to make accurate diagnosis, better understand their particular needs, and successfully perform the duties, thus enhancing the value perceived by themselves.

Third, patients should cooperate with physicians in the value co-creation process through accepting the guidance and following advice and consultancy (Yi \& Gong, 2013). As patients recognize their duties and responsibilities and what are expected from them, they would be more cooperative, and the value co-creation is likely to be successful, raising the perceived value.

In short, as patients attempt to participate in the treatment process, their perceived value can be increased. Thus:

H3: Patient participation has a positive impact on patient's perceived value of the health care service.

\subsection{Perceived value and customer satisfaction}

Customer satisfaction is a widely researched construct in the literature, which can be understood as the customer's emotional response to the fulfillment of needs, expectations, wishes, or desires (Keiningham et al., 2015). It is defined as an affective state as the result of comparing the expected performance and the perceived performance of a service (Oliver, 1980). 
In the health care context, patient satisfactions are regarded as a common evaluation in achieving the quality service and the goal of chronic treatment (Aliman \& Mohamad, 2013; Anderson \& Zimmerman, 1993; Porter, 2010) because it is related to patients' acceptance of treatment continuation, relationship with physician, patient adherence, and subsequent desired outcomes. Empirical evidence suggested that perceived value is a contributory factor to satisfaction (Yang \& Peterson, 2004), and that service providers can expend their effort to improve value perceived by customers in order to increase customer satisfaction. Vega-Vazquez et al. (2013) also substantiated a positive relationship between perceived value and customer satisfaction. Patients' participation in making decisions together with health care professionals could improve their disease status, reduce stress, and therefore increase their perceived value and satisfaction. Hence, it can be hypothesized that:

H4: Patients' perceived value has a positive impact on their satisfaction.

\subsection{Research model}

Figure 1 depicts the proposed research model. In this model the interaction behaviors of a service provider, the participation behaviors of customer, and customer's perceived value are all operationalized as second-order reflective constructs. Within the health care context, physician interaction behaviors are reflected by individuated interaction, relational interaction, and concerted interaction. Patient participation behaviors are indicated by information seeking, information sharing, and responsible behavior, while perceived value includes functional value and emotional value. 


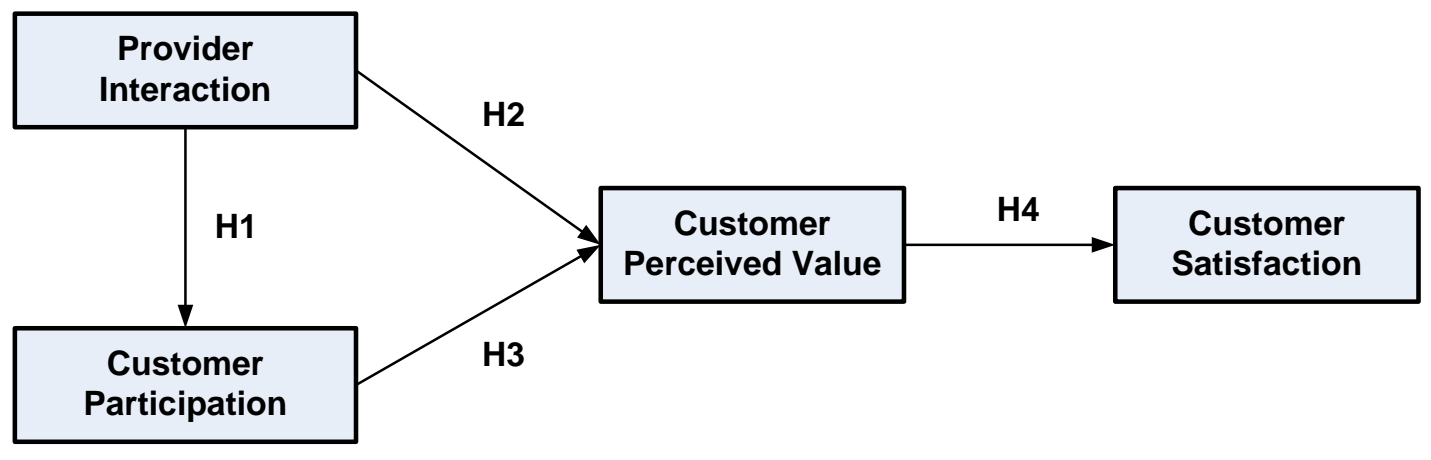

Figure 1: The proposed research model

\section{Method}

Quantitative data were collected via face-to-face interviews with a structured questionnaire at outpatient departments of 59 public and private hospitals in Ho Chi Minh City based on convenient sampling method. Applied at each interview site was the dyadic technique which matched one patient and the corresponding physician into a paired case. For each paired case, the chronic patient was first interviewed about his/her participation behaviors, perceived value, and satisfaction level, and then he or she was asked to name the physician for a following interview about physician's interaction behavior.

The scale measuring physician interaction behaviors is based on Karpen et al. (2011) and consists of 10 items reflecting three dimensions (individuated interaction, relational interaction, and concerted interaction). Patient participation behaviors are measured by 10 items reflecting three dimensions (information seeking, information sharing, and responsible behavior), and are adapted from Yi and Gong (2013). Patient perceived value, including functional value and emotional value, is measured by eight items, and satisfaction, measured by five items, which are adopted from Sweeney and Soutar (2001) and Aliman and Mohamad (2013). All scales are in the form of five-point Likert type. 


\section{Results}

\subsection{Sample characteristics}

A total of 320 pairs of responses (i.e., 320 cases) were collected and qualified for use in the data analysis. The sample characteristics are presented in Table 1. The statistics presented in this table show that the sample covers a diversity of respondents in terms of disease, frequency of visit, gender, and age group of patient and physician. Thus, the sample is appropriate for further analysis.

\section{Table 1}

Sample characteristics

\begin{tabular}{l|l}
\hline Hospital type & $65 \%$ \\
\hline Public & $35 \%$ \\
Private & $12 \%$ \\
\hline Chronic disease & $13 \%$ \\
\hline Cardiology & $10 \%$ \\
Hypertension & $20 \%$ \\
Diabetic & $9 \%$ \\
Asthma + COPD & $20 \%$ \\
Rheumatology, Hepatitis & $15 \%$ \\
Combined disease & \\
Others &
\end{tabular}

\section{Frequency of visit}

First time

Two times per month

$11 \%$

Two tim

$44 \%$

Once per month

$33 \%$

Once per 2 months 


\begin{tabular}{|c|c|c|c|c|}
\hline \multicolumn{5}{|l|}{ Gender } \\
\hline & & \multicolumn{3}{|l|}{ Physician } \\
\hline & & Male & & Female \\
\hline \multirow{2}{*}{ Patient } & Male & $24 \%$ & & $19 \%$ \\
\hline & Female & $29 \%$ & & $28 \%$ \\
\hline \multicolumn{5}{|c|}{ Age group } \\
\hline & & \multicolumn{3}{|c|}{ Physician } \\
\hline & & $25-35$ & $36-45$ & $46 \&$ above \\
\hline \multirow{4}{*}{ Patient } & $35 \&$ below & $4 \%$ & $5 \%$ & $6 \%$ \\
\hline & $36-45$ & $7 \%$ & $8 \%$ & $5 \%$ \\
\hline & $46-55$ & $5 \%$ & $11 \%$ & $6 \%$ \\
\hline & $56 \&$ above & $11 \%$ & $21 \%$ & $11 \%$ \\
\hline
\end{tabular}

\subsection{Validity and reliability of measures}

Exploratory factor analysis (EFA) and Cronbach's Alpha are first employed for preliminary assessment of dimensionality, reliability, and convergent validity of each scale. Accordingly, three items are eliminated due to low loadings on their designated factor. EFA factor loadings of the 30 remaining items range from 0.625 to 0.935 , and Cronbach's alpha of the nine scales ranges from 0.63 to 0.88 . Next, the 30 qualified items are submitted to confirmatory factor analysis (CFA) to examine the full measurement model. The test for normality shows that the 30 remaining items have Kurtosis values that range between -1.036 to 1.630 , and skewness values, from -0.883 to 0.183 , which indicates a slight deviation from normal distribution (Kline, 2011). Therefore, maximum likelihood (ML) is concluded to be an appropriate estimation method (Fabrigar et al., 1999).

The measurement model is further refined by eliminating eight more items having high covariance of the error terms. The CFA of the full measurement model results in satisfactory fit indices: Chi-square $=265.01 ; \mathrm{dF}=173 ; \mathrm{GFI}=0.931 ; \mathrm{CFI}=0.970$; TLI $=0.960 ;$ RMSEA $=0.041$. The HOETLER index of 247 is above the threshold value of 200, implying that the sample size is large enough for this analysis (Byrne, 2001). These results indicate an acceptable fit between the measurement model and the data having 
been collected. CFA factor loadings of items range from 0.53 to 0.90 , and composite reliabilities are from 0.57 to 0.87 . Correlation coefficients between pairs of constructs are within $0.26-0.84$ (below 1.00) (at $\mathrm{p}=0.05$-Anderson \& Gerbing, 1988). Thus, the measurement scales of the studied concepts are satisfactory in terms of reliability, convergent validity, and discriminant validity. This conclusion is made with a note of caution on the scales having AVE falling between 0.40 and 0.50 (lower than the common threshold of 0.50), yet being still usable (Barclay, 1991; Green et al., 1995).

\section{Table 2}

Assessment of measurement scales

\begin{tabular}{|c|c|c|c|c|c|}
\hline \multirow{2}{*}{ Construct } & \multirow{2}{*}{ Item } & \multicolumn{2}{|c|}{ EFA } & \multicolumn{2}{|c|}{ CFA } \\
\hline & & Loading & Alpha & Loading & AVE \& CR \\
\hline \multirow{3}{*}{ Individuated interaction } & DR_II1 & 0.843 & \multirow{3}{*}{0.736} & 0.88 & \multirow{3}{*}{$\begin{array}{r}\mathrm{AVE}=0.607 \\
\mathrm{CR}=0.752\end{array}$} \\
\hline & DR_II2 & 0.835 & & 0.66 & \\
\hline & DR_II3 & 0.748 & & eliminated & \\
\hline \multirow{4}{*}{ Relational interaction } & DR_RI4 & 0.625 & \multirow{4}{*}{0.670} & 0.73 & \multirow{4}{*}{$\begin{array}{c}\mathrm{AVE}=0.407 \\
\mathrm{CR}=0.573\end{array}$} \\
\hline & DR_RI5 & 0.751 & & eliminated & \\
\hline & DR_RI6 & 0.809 & & eliminated & \\
\hline & DR_RI7 & 0.665 & & 0.53 & \\
\hline \multirow{3}{*}{ Concerted interaction } & DR_CI20 & 0.864 & \multirow{3}{*}{0.660} & 0.63 & \multirow{3}{*}{$\begin{array}{c}\mathrm{AVE}=0.504 \\
\mathrm{CR}=0.668\end{array}$} \\
\hline & DR_CI21 & 0.864 & & 0.78 & \\
\hline & DR_CI23 & eliminated & & eliminated & \\
\hline \multirow{3}{*}{ Information seeking } & PT_IS24 & 0.935 & \multirow{3}{*}{0.855} & 0.86 & \multirow{3}{*}{$\begin{array}{c}\mathrm{AVE}=0.747 \\
\mathrm{CR}=0.855\end{array}$} \\
\hline & PT_IS25 & eliminated & & eliminated & \\
\hline & PT_IS26 & 0.935 & & 0.87 & \\
\hline \multirow{3}{*}{ Information sharing } & PT_ISH27 & 0.679 & \multirow{3}{*}{0.625} & 0.68 & \multirow{3}{*}{$\begin{array}{c}\mathrm{AVE}=0.419 \\
\mathrm{CR}=0.589\end{array}$} \\
\hline & PT_ISH28 & 0.775 & & 0.61 & \\
\hline & PT_ISH29 & 0.632 & & eliminated & \\
\hline
\end{tabular}




\begin{tabular}{|c|c|c|c|c|c|}
\hline \multirow{3}{*}{ Construct } & \multirow{2}{*}{ Item } & \multicolumn{2}{|c|}{ EFA } & \multicolumn{2}{|c|}{ CFA } \\
\hline & & Loading & Alpha & Loading & AVE \& CR \\
\hline & PT_ISH30 & 0.663 & & eliminated & \\
\hline \multirow{3}{*}{ Responsible behavior } & PT_RB31 & 0.792 & \multirow{3}{*}{0.625} & 0.63 & \multirow{3}{*}{$\begin{array}{c}\mathrm{AVE}=0.423 \\
\mathrm{CR}=0.594\end{array}$} \\
\hline & PT_RB32 & 0.768 & & eliminated & \\
\hline & PT_RB33 & 0.773 & & 0.67 & \\
\hline \multirow{4}{*}{ Functional value } & PT_FV38 & 0.841 & \multirow{4}{*}{0.873} & 0.72 & \multirow{4}{*}{$\begin{array}{c}\mathrm{AVE}=0.690 \\
\mathrm{CR}=0.869\end{array}$} \\
\hline & PT_FV39 & 0.907 & & 0.90 & \\
\hline & PT_FV40 & 0.811 & & eliminated & \\
\hline & PT_FV41 & 0.848 & & 0.86 & \\
\hline \multirow{4}{*}{ Emotional value } & PT_EV42 & 0.775 & \multirow{4}{*}{0.840} & 0.68 & \multirow{4}{*}{$\begin{array}{c}\mathrm{AVE}=0.571 \\
\mathrm{CR}=0.841\end{array}$} \\
\hline & PT_EV43 & 0.855 & & 0.81 & \\
\hline & PT_EV44 & 0.841 & & 0.80 & \\
\hline & PT_EV45 & 0.817 & & 0.72 & \\
\hline \multirow{5}{*}{ Satisfaction } & PT_CS48 & 0.875 & \multirow{5}{*}{0.883} & 0.86 & \multirow{5}{*}{$\begin{array}{r}\mathrm{AVE}=0.647 \\
\mathrm{CR}=0.845\end{array}$} \\
\hline & PT_CS49 & 0.897 & & 0.82 & \\
\hline & PT_CS50 & 0.886 & & eliminated & \\
\hline & PT_CS51 & eliminated & & eliminated & \\
\hline & PT_CS54 & 0.797 & & 0.73 & \\
\hline
\end{tabular}

\subsection{Structural model estimation and hypotheses testing}

Given the satisfactory fit of the measurement model, the proposed hypotheses are then tested using structural equation modeling. Estimating the proposed structural model using ML method results in a good fit: Chi-square $=290.756 ; \mathrm{dF}=197 ; \mathrm{CFI}=0.969$; $\mathrm{GFI}=0.925 ; \mathrm{TLI}=0.964 ; \mathrm{RMSEA}=0.039$. The loadings of items on their respective latent constructs range from 0.55 to 0.90 .

Based on the standardized path coefficients (Table 3), it is found that all four hypotheses are supported. As predicted, physician interaction behaviors have a strong 
and positive impact on patient participation behaviors $(\beta=0.62 ; p<0.01)$ as well as value perceived by patient $(\beta=0.31 ; p<0.01)$; patient participation behaviors are strongly and positively associated with their perceived value $(\beta=0.58 ; p<0.01)$; and patient perceived value has a strong and positive impact on their satisfaction $(\beta=0.87$; $p<0.01)$.

The results also show that the proportion of the variance in patient's perceived value explained by patient participation and physician interaction behaviors is considerably high, at $64 \%$, and patient perceived value explains $76 \%$ of variance of patient satisfaction. The results of hypothesis testing are summarized in Table 3, along with the standardized parameter estimates.

\section{Table 3}

Standardized estimates $($ sample size $=320$ )

\begin{tabular}{llccc}
\hline & Hypothesis & $\begin{array}{c}\text { Standardized } \\
\text { coefficients }\end{array}$ & p-value & Result \\
\hline $\mathrm{H}_{1}(+)$ & Physician interaction $\rightarrow$ Patient participation & $0.62 * * *$ & 0.000 & Supported \\
$\mathrm{H}_{2}(+)$ & Physician interaction $\rightarrow$ Perceived value & $0.31^{* * *}$ & 0.002 & Supported \\
$\mathrm{H}_{3}(+)$ & Patient participation $\rightarrow$ Perceived value & $0.58^{* * *}$ & 0.000 & Supported \\
$\mathrm{H}_{4}(+)$ & Perceived value $\rightarrow$ Patient satisfaction & $0.87 * * *$ & 0.000 & Supported \\
\hline
\end{tabular}

Notes: $* * *$ denotes $1 \%$ significance level, and $p$-values of standardized estimates are obtained from bootstrap estimation (post-test estimation).

\section{Discussion}

Literature advocated that customer and service provider co-create value (Grönroos, 2008) and that the value is co-created through resource integration and interaction (Gummesson \& Mele, 2010). In this specific study in the context of health care service, the results provide more concrete empirical evidence on the roles and mechanism in which the two sides, i.e. service encounters and customers, interact directly within the joint sphere to co-create value for customers.

Firstly, co-creation of value requires that services not be solely produced by the firm and customers not be passive recipients of value; it reflects the reality that customers must participate in the service creation process (Vargo \& Lusch, 2004). Amid the health care setting, the participation or involvement of customers is compulsory. Previous 
studies have shown that patient participation behaviors taken in the forms of information sharing and information seeking are the key to patient-physician relationship and patient satisfaction (Epstein \& Street, 2011; Holman \& Lorig, 2004; Yi \& Gong, 2013). However, participating in a service process also means that customers must spend more of their own resources in addition to the amount of money they pay. In the customer view, it is important whether there is an additional value in the trade-off between spending additional resources and receiving a more customized and/or better quality service. With the empirical result indicating the positive effect of customer participation on customer perceived value in the health care context, the current study provides an empirical evidence to consolidate the notion that the more actively a patient participates, the better service value he or she would obtain. In other words, this study is in strong support of the view on customers as co-creators or co-producers of value in the foundational premises of service dominant logic as suggested by Vargo and Lusch (2004) and Grönroos (2008).

Secondly, the participation of service customers in a service must be inquired in the context of its interaction with the service provider (Gummesson \& Mele, 2010). The current study extends our understanding on this interaction by specifying the role of the two sides. Particularly, it is founded that there is a positive and significant effect of interaction behaviors of the service provider (i.e. service encounters) on customer participation. That is, the extent of customers' participation is dependent on how the service provider interacts with them in the role of an initiator. Given the notion that both sides are co-creators of value, this result indicates that service encounters actually serve the initiative role in activating service customers to participate. This role of service provider is crucial in various service contexts where customer participation is a required part of the value co-creation procedure but customers are reluctant or not confident to participate, such as health care, education, consulting or other professional services (Lengnick-Hall et al., 2000).

The third issue relates to capability of service encounters in directly creating value for customers through their interaction behaviors. In this case of health care service, physician interaction behaviors are positively associated with patient perceived value. Interaction activities undertaken by physicians may include detailed discussion with patients about the treatment plan, the explanation about how patients can best assist the healing process, or any additional information sources they may find useful, which in turn will translate into more informed decisions. In addition, as physicians attempt to 
address patients individually, spend time listening to their concerns, and demonstrate sympathy and care, patients can feel emotionally supported. Thus, confidence can be built, and these patients can make better and more informed choices regarding their treatment procedure. All of these potential outcomes will definitely enhance customer perception of service value in both process and outcome forms.

From a practical view, some managerial implications can be drawn from the results of this study. In Vietnam, one of the most challenging barriers for patient participation in the treatment process stems from inadequate information and knowledge on the patient side. Additionally, the lack of commitment and interpersonal and communication skills on the physician side may potentially lead to therapeutic failure. It would be more difficult to enhance patient participation in public hospitals since physicians may not have sufficient time to spend on consulting every single patient due to their heavy workload (Krueger et al., 2001). Therefore, measures to improve the physician's interpersonal and communication skills can increase collaboration and interaction between the two sides, which will then enhance patient satisfaction and lead to positive effects on treatment adherence and outcomes.

\section{Concluding remarks}

In aggregation, the current study contributes to extend our knowledge about the twofold roles of interaction behaviors of service encounters in the context of heath care. Interaction behaviors are primarily a reflection of the customer-oriented behavior (COB), a critical success factor in any high-contact service (Mechinda \& Patterson, 2011). Moreover, it plays a crucial role in activating the participation of customers to contribute their resources for a better service production, leading to higher value perception and customer satisfaction. From the customer view, actively participating in a health care service requires more resources; it is, nevertheless, worthy to do so because it creates much greater value-in-use for them.

From the methodological perspective, one striking feature of this study is the dyadic approach to data collection. While many prevailing quantitative studies employed survey data collected from single informants, the present study relies on paired-case approach to data collection for a better reflection of the nature of two-side interaction. More importantly, it is considered one among the most effective ways to minimize the 
common method bias in the survey data which leads to systematic errors (Podsakoff et al., 2003).

There are a number of limitations of this study, which suggest certain areas for further research. From the general theoretical view on the provider-customer interaction to cocreate value, this research is confined to one service industry context (i.e. health care). Given the diverse nature of services, further research is suggested to examine the roles of interaction in services with different features in terms of levels of contact (high vs. low), knowledge distance between customers and providers (high vs. low), target of service acts (object vs. human), relation base (membership vs. contract-based). Another issue that is worthy to explore relates to the changing roles in the interaction between service encounters and customers in different stages of the service value co-creation, which are out of the direct, interactive joint sphere of the process

\section{References}

Alam, I. (2011). Process of customer interaction during new service development in an emerging country. The Service Industries Journal, 31(16), 2741-2756.

Aliman, N. K., \& Mohamad, W. N. (2013). Perceptions of service quality and behavioral intentions: A mediation effect of patient satisfaction in the private health care in Malaysia. International Journal of Marketing Studies, 5(4), 15-29.

Anderson, J. C., \& Gerbing, D. W. (1988). Structural equation modeling in practice: A review and recommended two-step approach. Psychological Bulletin, 103(3), 411-423.

Anderson, L. A., \& Zimmerman, M. A. (1993). Patient and physician perceptions of their relationship and patient satisfaction: A study of chronic disease management. Patient Education and Counseling, 20(1), 27-36.

Barclay, D. W. (1991). Interdepartmental conflict in organizational buying: The impact of the organizational context. Journal of Marketing Research, 28(2), 145-159.

Berry, L. L., \& Bendapudi, N. (2007). Health care: A fertile field for service research. Journal of Service Research, 10(2), 111-122.

Bitner, M. J., Danaher, T. S., \& Gallan, A. S. (2014). Journal of Service Research special section on health service research: A multidisciplinary perspectives. Journal of Service Research, 17(4). doi:10.1177/1094670514548327

Bitner, M. J., Faranda, W. T., Hubbert, A. R., \& Zeithaml, V. A. (1997). Customer contributions and roles in service delivery. International Journal of Service Industry Management, 8(3), 193-205.

Bodenheimer, T., Wagner, E. H., \& Grumbach, K. (2002). Improving primary care for patients with chronic illness: The chronic care model, Part 2. Jama, 288(15), 1909-1914. 
Byrne, B. M. (2001). Structural equation modeling with AMOS, EQS, and LISREL: Comparative approaches to testing for the factorial validity of a measuring instrument. International Journal of Testing, 1(1), 55-86.

Cegala, D. J., Street, R. L. Jr., \& Clinch, C. R. (2007). The impact of patient participation on physicians' information provision during a primary care medical interview. Health Communication, 21(2), 177185.

Chan, K. W., Yim, C. K., \& Lam, S. S. (2010). Is customer participation in value creation a doubleedged sword? Evidence from professional financial services across cultures. Journal of Marketing, 74(3), 48-64.

Eldh, A. C., Ekman, I., \& Ehnfors, M. (2006). Conditions for patient participation and non-participation in health care. Nursing Ethics, 13(5), 503-514.

Epstein, R. M., \& Street, R. L. (2011). The values and value of patient-centered care. The Annals of Family Medicine, 9(2), 100-103.

Fabrigar, L. R., Wegener, D. T., MacCallum, R. C., \& Strahan, E. J. (1999). Evaluating the use of exploratory factor analysis in psychological research. Psychological Methods, 4(3), 272-299.

Green, D. H., Barclay, D. W., \& Ryans, A. B. (1995). Entry strategy and long-term performance: Conceptualization and empirical examination. Journal of Marketing, 59(4), 1-16.

Grönroos, C. (2008). Service logic revisited: Who creates value? And who co-creates? European Business Review, 20(4), 298-314.

Grönroos, C., \& Ravald, A. (2011). Service as business logic: Implications for value creation and marketing. Journal of Service Management, 22(1), 5-22.

Grönroos, C., \& Voima, P. (2012). Making sense of value and value co-creation in service logic. Retrieved from http://hdl.handle.net/10138/29218.

Grönroos, C., \& Voima, P. (2013). Critical service logic: Making sense of value creation and cocreation. Journal of the Academy of Marketing Science, 41(2), 133-150.

Gummesson, E., \& Mele, C. (2010). Marketing as value co-creation through network interaction and resource integration. Journal of Business Market Management, 4(4), 181-198.

Hausman, A. (2004). Modeling the patient-physician service encounter: Improving patient outcomes. Journal of the Academy of Marketing Science, 32(4), 403-417.

Holman, H., \& Lorig, K. (2004). Patient self-management: A key to effectiveness and efficiency in care of chronic disease. Public Health Reports, 119(3), 239-243.

Karpen, I. O., Bove, L. L., \& Lukas, B. A. (2011). Linking service-dominant logic and strategic business practice: A conceptual model of a service-dominant orientation. Journal of Service Research. doi: 1094670511425697

Karpen, I. O., Bove, L. L., Lukas, B. A., \& Zyphur, M. J. (2014). Service-dominant orientation: Measurement and impact on performance outcomes. Journal of Retailing, 91(1), 89-108.

Keiningham, T. L., Cooil, B., Malthouse, E. C., Buoye, A., Aksoy, L., Keyser, A. D., \& Lariviere, B. (2015). Perceptions are relative: An examination of the relationship between relative satisfaction metrics and share of wallet. Journal of Service Management, 26(1), 2-43. 
Kelley, S. W., Donnelly, J. H. Jr., \& Skinner, S. J. (1990). Customer participation in service production and delivery. Journal of Retailing, 66(3), 315-335.

Kellogg, D. L., Youngdahl, W. E., \& Bowen, D. E. (1997). On the relationship between customer participation and satisfaction: Two frameworks. International Journal of Service Industry Management, 8(3), 206-219.

Kline, R. B. (2011). Principles and practice of structural equation modeling. NY: Guilford Press.

Krueger, G., Koo, J., Lebwohl, M., Menter, A., Stern, R. S., \& Rolstad, T. (2001). The impact of psoriasis on quality of life: Results of a 1998 National Psoriasis Foundation patient-membership survey. Archives of Dermatology, 137(3), 280-284.

Larsson, R., \& Bowen, D. E. (1989). Organization and customer: Managing design and coordination of services. Academy of Management Review, 14(2), 213-233.

Lengnick-Hall, C. A., Claycomb, V., \& Inks, L. W. (2000). From recipient to contributor: Examining customer roles and experienced outcomes. European Journal of Marketing, 34(3-4), 359-383.

Levitt, T. (1972). Production-line approach to service. Harvard Business Review, 50(5), 41-52.

Lovelock, C. H., \& Young, R. F. (1979). Look to consumers to increase productivity. Harvard Business Review, 57(3), 168-178.

Lusch, R. F., \& Vargo, S. L. (2006). Service-dominant logic: Reactions, reflections, and refinements. Marketing Theory, 6(3), 281-288.

McColl-Kennedy, J. R., Vargo, S. L., Dagger, T. S., Sweeney, J. C., \& van Kasteren, Y. (2012). Health care customer value cocreation practice styles. Journal of Service Research. doi: 1094670512442806.

Mechinda, P., \& Patterson, P. G. (2011). The impact of service climate and service provider personality on employees' customer-oriented behavior in a high-contact setting. Journal of Services Marketing, 25(2), 101-113.

Oliver, R. L. (1980). A cognitive model of the antecedents and consequences of satisfaction decisions. Journal of Marketing Research, 17(4), 460-469.

Ordanini, A., \& Parasuraman, A. (2010). Service innovation viewed through a service-dominant logic lens: A conceptual framework and empirical analysis. Journal of Service Research. doi: 1094670510385332.

Podsakoff, P. M., MacKenzie, S. B., Lee, J.-Y., \& Podsakoff, N. P. (2003). Common method biases in behavioral research: A critical review of the literature and recommended remedies. Journal of Applied Psychology, 88(5), 879-903.

Porter, M. E. (2010). What is value in health care? New England Journal of Medicine, 363(26), 24772481.

Prahalad, C. K., \& Ramaswamy, V. (2000). Co-opting customer competence. Harvard Business Review, 78(1), 79-90.

Prahalad, C. K., \& Ramaswamy, V. (2004). Co-creation experiences: The next practice in value creation. Journal of Interactive Marketing, 18(3), 5-14. 
Ramaswamy, V., \& Gouillart, F. (2010). Building the co-creative enterprise. Harvard Business Review, $88(10), 100-109$.

Sinnya, U. (2014). The role of customers on the co-creation of service climate in a restaurant setting: A qualitative study. $\quad$ Retrieved from http://www.divaportal.org/smash/get/diva2:717608/FULLTEXT01.pdf.

Sweeney, J. C., \& Soutar, G. N. (2001). Consumer perceived value: The development of a multiple item scale. Journal of Retailing, 77(2), 203-220.

Tanev, S., Bailetti, T., Allen, S., Milyakov, H., Durchev, P., \& Ruskov, P. (2011). How do value cocreation activities relate to the perception of firms' innovativeness? Journal of Innovation Economics \& Management, 7(1), 131-159.

Vargo, S. L., \& Lusch, R. F. (2004). Evolving to a new dominant logic for marketing. Journal of Marketing, 68(1), 1-17.

Vargo, S. L., Maglio, P. P., \& Akaka, M. A. (2008). On value and value co-creation: A service systems and service logic perspective. European Management Journal, 26(3), 145-152.

Vega-Vazquez, M., Ángeles Revilla-Camacho, M., \& Cossío-Silva, F. (2013). The value co-creation process as a determinant of customer satisfaction. Management Decision, 51(10), 1945-1953. http://dx.doi.org/10.1108/MD-04-2013-0227

Venkatesh, J., \& Balaji, M. D. (2012). Relational impact of physicians' interaction behavior in healthcare. Golden Research Thoughts, 1(7).

Wikström, S. (1996). The customer as co-producer. European Journal of Marketing, 30(4), 6-19.

Yang, Z., \& Peterson, R. T. (2004). Customer perceived value, satisfaction, and loyalty: The role of switching costs. Psychology \& Marketing, 21(10), 799-822.

Yi, Y., \& Gong, T. (2013). Customer value co-creation behavior: Scale development and validation. Journal of Business Research, 66(9), 1279-1284.

Yi, Y., Nataraajan, R., \& Gong, T. (2011). Customer participation and citizenship behavioral influences on employee performance, satisfaction, commitment, and turnover intention. Journal of Business Research, 64(1), 87-95.

Zeithaml, V. A. (1988). Consumer perceptions of price, quality, and value: A means-end model and synthesis of evidence. Journal of Marketing, 52(3), 2-22.

Zolnierek, B. H. K., \& DiMatteo, R. M. (2009). Physician communication and patient adherence to treatment: A meta-analysis. Medical Care, 47(8), 826-834. doi:10.1097/MLR.0b013e31819a5acc 